\title{
CONCEPT OF "ABSOLUTE RIGHT" OF G. HEGEL IN MODERN CHANGING WORLD
}

\author{
Volodymyr Vynnychenko Central Ukrainian State Pedagogical University;
} spharchenko_1@ukr.net

\begin{abstract}
The phenomenon of "absolute law" as a basic principle in the architecture of universal moral and ethical paradigms, as well as modern institutional and legal systems is conceptualized in the study. The key task of the study was to measure the "absolute" - "right" relevance in the pan-logical philosophical and legal paradigm of G. Hegel's discourse. The philosophicallegal and philosophical-historical approaches to compare the philosopher's fundamental positions, representing law as a social norm and a moral will, as well as to check their compatibility in historical and logical discourses were used. Hermeneutic method allowed interpreting G. Hegel's texts, which resulted in the correct use of key categories of "law", "right", "moral," "morality." As a result of the study it was confirmed that G. Hegel's concept of "absolute law" is based on the idea of self-development of the absolute purpose of the Will as an ascent to Good, which ultimate link is the realization of the truth of Good. And only then it will be able to come close to absolute knowledge. At the climax of its development, it comprehends an absolute ldea. Absolute law becomes conscious at the center of its self and free, capable of infinite self-development. Absolute right is the embodiment of the "pure idea of freedom". Absolute right is identical to the Absolute Spirit.
\end{abstract}

Key words: right, unright, absolute purpose of the Will, absolute right.

\section{Introduction}

Philosophical science at certain moments of life necessarily returns to classical theories, which are universal and fundamental in nature and meaning. It is important to emphasize that such a turn is possible in the conditions of crisis or transition of civilization and society in a qualitatively different state. Psychologically we gravitate to the equilibrium in the state, society, in the professional sphere, in everyday life and in personal space. However, in our memory unbalanced periods, rhizomic moments of history reflect more. Breaking of existing world-view values and general educational standards, the collapse of hopes and aspirations, the destruction of the usual foundations of the society and the State do not go unnoticed, but on the contrary lead to tragic consequences. At the same time, a person loses his footing, feels insecure. As a result, the basic principles of the State and the law are being destroyed, in turn creating willfulness and lawlessness.

In today's globalized world, where competition between different centers of power is becoming more intense, not all players are equal. It can be observed that international legal institutions often act asymmetrically towards certain members of the world community, and their strategic interests are ignored.

In everyday life, on the one hand, life is becoming more comfortable, because modern technologies are associated with enormous opportunities that allow individuals to be realized in any professional sphere. But, on the other hand, society is becoming more and more unfair and this is the main contradiction in the modern world. Thus, a person re-analyzes and understands the categories of "justice" and "injustice", "good" and "evil", "good" and "lack of good". In turn, "state", "law", "morality" are categories that were marked in Antiquity, but to an even greater extent they are updated now.

Indeed, we always return to the experience of the ancients, and the further we delve into the past, the wiser our mysterious ancestors are comprehended. Moreover, if they teach us life wisdom and morality, classical philosophical theories contribute to the most in-depth understanding of the principles of the society and the state building, help to develop moral and ethical norms of individual and public life. At some point, universal commandments as absolute unwritten divine truths are firmly rooted in legal discourse. This means that at every stage of the historical development of social relations and institutional and legal systems, the idea of absolute law is presented as a key mechanism for building a just society.

\section{The aim and tasks}

This study conceptualizes the phenomenon of "absolute law" as a basic principle in the architecture of universal moral and ethical paradigms, as well as modern institutional and legal systems.

The key task of the study is to measure the relevance of "absolute" and "right" in the discourse of the pan-logical philosophical and legal paradigm of G. Hegel.

\section{Research methods}

The author in the process of the study uses philosophical-legal and philosophical-historical approaches to compare the fundamental positions of G. Hegel, representing law as a social norm and law as a moral will, as well as to check their compatibility in the historical and logical discourses.

Also, the hermeneutic method, which allows interpreting the texts of G. Hegel from the point of view of mental comprehension, is used (Janicaud, 1999: 25). This method contributes to the effective psychological processing of textual information, which results in the correct use of key categories following from the text, such as: "law", "right", "moral" and "morality". G. Hegel's works form special levels, phases and factors of understanding.

\section{Research results}

As we have already said, we return to the work of classical philosophers to find a foothold, especially when it comes to moral principles. G. Hegel argued that the truth about law, morality, and state is as old as it is directly given in public laws, public morality, and religion and is generally known. What else does this truth need? For the thinking spirit which is not satisfied with having it in such a way that is most accessible to it, if it is not to be grasped and that to the rational content itself is given a reasonable form, that it is justified for a free thinking that cannot stop at this point, regardless of whether it is based on the external 
positive authority of the state, on the general consent of the people, on the authority of the inner sense and heart and directly determining the testimony of the spirit; comes from himself and that is why it requires knowledge of oneself in the deepest unity with the truth? (Gegel, 1990: 46). The thinker draws attention to the fact that although the legal truth is ancient, its origins are not fully explored and there are even deeper beginnings that give rise to it.

On the one hand, when describing any phenomenon, we need, first of all, to push away from something concrete. That is, to trace whether there are social prerequisites for the emergence of the law or it is highly transcendentally. G. Hegel defined the law as positive in general: (a) because of the form of recognition, this legitimate authority is the principle of its knowledge, the science of positive law; (b) the content of this right is positive because of the special national character of the people, the degree of their historical development and the connection of all those relations that belong to the realm of natural necessity; (c) because of the need for the legislative system to contain the application of a general concept to a particular, externally given state of subjects and cases, an application that is no longer speculative thinking and development of the concept, but reasonable by bringing the private under the general; (d) as a result of the latest definitions required to make decisions (Gegel, 1990: 61-62). It follows that the law, on the one hand, is a derivative of all public relationships that have developed historically, and it is legitimized in a collective Spirit as a general concept and as a set of all legal knowledge. The "transcendence" of the legal idea has to do with its knowledge and the conditions of our legal experience.

On the other hand, the law is transcendental, and therefore it is absolute. G. Hegel also points out that the right is a being at all and this being at all is a being of free will. Thus the right is generally freedom as an idea (Gegel, 1990: 89). In a strict philosophical sense, "transcendence" of law means staying beyond possible experience. That is, the right as an "absolute right" is derived from an absolute idea that produces the freedom of abstract will.

G. Hegel confirmed that the right is, first of all, the direct existence, which gives itself freedom directly. It is: (a) possession, which is the property. Freedom here is the freedom of the abstract will in general, or that is why of a single person who is related only to himself; (b) the person, distinguishing itself from itself, refers to another person, and both possess for each other this being only as owners. Their existence in itself gets to exist by transferring the property of one to the property of another, with the common will and preservation of their right - in the contract; (c) Will as (a) in its relation to itself, distinguished not from the other person (b), but in itself, is as a special will, different from itself and opposite to itself in itself and for itself being, - unright (Unrecht) and crime (Gegel, 1990: 99). Unright is a legal form of dysnomy (lawlessness). The thinker introduces this category to capture a special kind of Will that demonstrates arbitrariness and its isolation from the abstract and the abstract law.
G. Hegel notes that in the treaty the right in itself as put is its internal universality as a general arbitrariness and special will. This phenomenon of law, in which it and its essential given being, a special will, directly, coincidentally, coincide, goes into the unright in appearance, in opposition to each other right in itself and special will, in which the right in itself becomes special right. However, the truth of this appearance is that it is insignificant and that the right is restored by denying that denial; through this process of its mediation, of returning to itself from its negation, it defines itself as real and active, whereas at first it was only in itself and something immediate (Gegel, 1990: 137). Right and unright are presented here as "denial of denial" as something opposite to each other, similar to the Kantian antonyms that give rise to various binary contradictions. On the other hand, they are interconnected and interdependent.

G. Hegel defines abstract law as a coercive right, because unright towards him is a violence over this being of my freedom in the external thing; the preservation of this existence as opposed to violence is thus external action and violence that removes that first violence (Gegel, 1990: 143). The model of social reality and the form of government present at a particular historical moment, as well as the established configuration of public relations, give rise to all existing contradictions and conflicts. Because of their inefficiency, all kinds of unright are created, reproducing numerous crimes.

G. Hegel concludes that it is the right of moral will that contains the following three sides: (a) the abstract, or formal, right of action to ensure that its contents, as it is carried out in the direct of being, are generally mine, so that it is thus the intention of subjective will; (b) the special thing in the act is its inner content, namely, how it is defined by its universal character for me, what constitutes the value of the act and what it means to me, what constitutes the intention; (c) its content as my special purpose, my private subjective being is a blessing; (d) this content as an internal, simultaneously erected in its universality both in itself and for itself the existing objectivity, is the absolute purpose of the Will, the Good, acting in the sphere of reflection, together with the opposite of subjective universality, partially together with evil, partially along with the conscience (Gegel, 1990: 159-160). Absolute right in G. Hegel's philosophical system is the final link of the development of the absolute purpose of the Will, passing all stages of the ascent to Good, and through goodness to absolute knowledge. In its development it comprehends an absolute idea. Absolute right becomes conscious and free, capable of selfdevelopment. It is relevant to the absolute spirit.

Hegel's concept provides for the existence of all necessary conditions in society and the state, which would make it possible to climb to a higher level of development (Gegel, 1990: 29). We are talking about strong moral supports. In today's society, however, the notions of good and law are blurred.

In this regard, let us turn to Z. Bauman, who emphasizes that today's agenda is not the task of building a new and better order, which Will replace the old and flawed one - at least these tasks are on the 
agenda of the state where the presence of the political life should take place. Therefore, the "solid smelting" as a constant feature of modernity has acquired a new meaning, and now it is aimed at a new purpose. One of the main consequences of this change of purpose is the disappearance of forces capable of keeping the issue of order and the system on the political agenda. Solid bodies, whose turn to be thrown into the melting crucible has come, and which are already in the process of melting in our time, a time of fluidity, they are connections that fix individual actions into collective plans and actions - patterns of communication and coordination between individual lines of conduct, on the one hand, and the political actions of people's groups, on the other (Бауман, 2008: 12). It can be said that in this case the absolute purpose of the Will cannot be realized, because the collective purpose of the Will is aimed at meeting utilitarian needs.

Z. Bauman shows that modern patterns and configurations are no longer set and much less selfevident; there are too many of them, they collide with each other, and their instructions contradict each other, so that they are all largely devoid of their coercive, limiting power. Their character has changed and accordingly to this they are reclassified as items on the list of individual tasks. Instead of serving as a prerequisite for a style of behavior and setting the framework for determining a life course, they follow it (followed by it), formed and changed under the influence of its twists and turns. The forces of liquefaction have moved from system to society, from politics to life settings or dropped from macro- to microlevel of social dormitories (Бауман, 2008: 14). This means that the essence of legal and legislative institutions is leveled, and the guidelines of life are lost. In such circumstances, the unright is prevailing.

Z. Bauman defined modernity as multi-value, and its offensive and promotion can be tracked by many and various markers. However, as a possible difference, determining the other differences, one feature of modern life and its currents stand out, a key feature from which all other characteristics flow. This feature is the changing relationship between space and time. Modernity begins when space and time are separated from life practices and from each other, and so they can be understood as different and mutually independent categories of strategy and action when they are no longer, as they have been for centuries, closely related and therefore barely discernible aspects of life experience, anchored by a stable, obvious and indestructible mutually unambiguous conformity. Modern time has a history, it has a history because of the ever-expanding bandwidth - lengthening of stretches of space that can be passed, crossed, covered or conquered - per unit of time. Time acquires history, as the only speed of movement through space (as opposed to an unchanging, essentially, space that cannot be stretched or compressed) becomes a matter of agility, imagination and resourcefulness of man (Бауман, 2008: 15). Absolute spirit in such a model of history cannot be self-fulfilling. He should look for other outlets in the dynamics of constant variability.

\section{Discussion}

In national philosophy, many researchers consider modernity in the context of globalization and networking technologies. In particular, L. Drotyanko noted that the intensification of globalization processes is carried out due to the introduction of informatization on them and they form various social spheres (Дротянко, 2018: 12). Let's agree with this thesis. In various States, legal institutions and legislatures were shaped by their own cultural and historical traditions, but globalization was «superimposed» on them by the principles of the application of legal norms. This creates contradictions and makes intercultural dialogue more difficult. Forcing to «abandon of one's own» leads to the rhizomic character of social space.

In his turn, S. Yagodzinsky proved that in the conditions of the information society, the relevance of virtual social space defines a new contour of social interactions, sets new rules of existence for most social practices (Ягодзінський, 2018: 39). Moreover, these rules are tightened only for "outsiders", while "natives" live in a comfortable and familiar world for themselves.

This gradually strengthens all forms of legal dysnomy, including the virtual space. In this connection, S. Ordenov concluded that any universal and social guarantees that meet the basic principles of building a society, in an asocial state threaten the existing system (Орденов, 2018: 74). The author means that fair laws and the rule of law eliminates any attempt to unbalance the existing state system.

\section{Conclusion}

Thus, G. Hegel's concept of "absolute law" is based on the idea of self-development of the absolute purpose of the Will. At the same time, the ultimate link in the development of the absolute purpose of the Will, which is transformed at every stage of the ascent to Good, is the realization of the truth of Good. And only then it will be able to come close to absolute knowledge. At the climax of its development, it comprehends an absolute idea. Absolute law becomes conscious and free at the center of its self, capable of infinite self-development. Absolute right is the embodiment of the "pure idea of freedom". Absolute right is identical to the Absolute Spirit.

Absolute spirit is the highest category of Hegel's philosophical system, meaning the most developed form of being an absolute idea, the highest specificity. Absolute spirit is a self-aware absolute idea. Forms of absolute spirit as self-awareness of an absolute idea are art, religion and philosophy, in which the absolute idea completes the process of self-knowledge and achieves "absolute knowledge". At the same time, the Absolute Spirit finally reveals and captures its essence. Absolute law recognizes itself in the art of law, belief in justice and the philosophy of law. Therefore, the Absolute Right is relevant to the absolute spirit.

In the case of an unstable modernity and a rhizomic history, the concept of "absolute right" helps to identify inconsistencies in the development of institutional and legal systems.

The relevance of history is the fault of the root foundations of the development of the world. At the same time, there is a fundamentally non-linear way of 
organizing the integrity of the social space. In this unbalanced state, opportunities are opened for internal immanent mobility, as well as for interpretive pluralism in the sphere of legal relations. Such conditions set the stage for the presumption of destruction of traditional notions of the structure of public relations, leveling the idea of integrity as such and the law in general.

Absolute spirit in this model of history will not be able to develop and self-exercise. It loses its importance in the dynamics of constant variability. The absolute purpose of the Will cannot be realized, because the collective purpose of the Will is aimed at meeting utilitarian and narrow needs.

\section{Literature}

1.

Г. В. Ф. Гегель; Гегель Г. В. Ф. Философия права , М.: Мысль, 1990. 524 [2] с.

3. Дротянко Л. Г. Інтенсифікація глобалізаційних процесів в інфрормаційну еру / Л.Г.Дротянко // Вісник Національного авіаційного університету. Серія: Філософія. Культурологія: Збірник наукових праць. - Вип. 1 (27) - К.: НАУ, 2018. - C. 9-13.

4

Орденов С. С. Право і неправо в детермінанті суспільних відносин. / С. С. Орденов // Вісник Національного авіаційного університету. Серія: Філософрія. Культурологія: Збірник наукових праць. - Вип. 1 (27) - К.: НАУ, 2018. - С. 6776.

\section{С.П. Харченко}

КОНЦЕПЦИЯ «АБСОЛЮТНОГО ПРАВА» Г. ГЕГЕЛЯ В УСЛОВИЯХ СОВРЕМЕННОГО МЕНЯЮЩЕГОСЯ МИРА

В данном исследовании осуществляется концептуализация феномена «абсолютного права» как базового принципа в архитектонике универсальных морально-этических парадигм, а также современных институционально-правовых систем. В исследовании, в дискурсе панлогической философско-правовой парадигмы Г. Гегеля, измеряется релевантность «абсолюта» и «права». Показано, что гегелевские работы сформировали особые уровни, фразы и факторы понимания. В результате концепция Г. Гегеля об «абсолютном праве» базируется на идее саморазвития абсолютной цели воли. При этом конечным звеном развития абсолютной цели воли, которая преобразуется на каждом этапе восхождения к добру, является постижение истины добра. И только после этого она сможет приблизиться к абсолютному знанию. В кульминации своего развития она постигает абсолютную идею. Абсолютное право становится сознательным в центре своей самости и свободным, способным к бесконечному саморазвитию. Абсолютное право есть воплощение «чистой идеи свободы». Абсолютное право тождественно Абсолютному духу.

Ключевые слова: право, неправо, абсолютная цель воли, абсолютное право.

\section{С.П. Харченко}

КОНЦЕПЦІЯ «АБСОЛЮТНОГО ПРАВА» Г. ГЕГЕЛЯ В УМОВАХ СУЧАСНОГО МІНЛИВОГО СВІТУ

Вступ. Показано, що міжнародні правові інститути застосовують силу закону не симетрично по відношенню до тих чи інших представників світового співтовариства, а їхні стратегічні інтереси ігноруються. Мета. У даному дослідженні здійснено концептуалізацію феномену «абсолютного права» як основного принципу в архітектоніці універсальних моральних і етичних парадигм, а також сучасних інституційно-правових систем. У дискурсі панлогічної філософсько-правової парадигми Г. Гегеля вимірюється актуальність «абсолюту» і «права», що є ключовим завданням. Методологія дослідження. Філософрсько-правові та філософсько-історичні підходи використовуються для порівняння фундаментальних позицій Г. Гегеля, що представляють «Закон» як соціальну норму і «Закон» як моральну волю, а також здійснено перевірку їхньої сумісності в дискурсах історичного і логічного. Метод герменевтики дозволив інтерпретувати тексти Г. Гегеля з погляду психічного розуміння. Цей метод сприяв ефективній психологічній обробці текстової інформації, що призвело до правильного використання ключових категорій, які представлені в тексті - «закон», «право», «моральність», «мораль». Показано, що гегелівські роботи сформували спеціальні рівні, фрази та чинники розуміння. Результати. Обґрунтовано, що право, с одного боку, являється похідною всіх суспільних зв'язків та відносин, що склалися історично, а також воно легітимується в деякому колективному Дусі як загальне поняття та як сукупність усіх правових знань. Обговорення. Підтверджено, що в різних державах правові інститути й законодавчі органи формувалися 3 урахуванням власних культурних та історичних традицій, однак у процесі глобалізації відбувається «накладання» на них західних принципів застосування правових норм. Висновки. Концепція Г. Гегеля про «абсолютне право» ґрунтується на ідеї самостійного розвитку абсолютної мети волі. У той же час, кінцева ланка в розвитку абсолютної мети волі, яка перетворюється на кожному етапі сходження на добро, є реалізація правди добра. Тільки тоді вона зможе наблизитися до абсолютного знання. Кульмінацією її розвитку є розуміння абсолютної ідеї. Абсолютне право стає свідомим в центрі своєї самості і свободним, здатним до нескінченного саморозвитку. Абсолютне право є втіленням «чистої ідеєю свободи». Абсолютне право ідентичне абсолютному духу.

Ключові слова: право, неправо, абсолютна мета волі, абсолютне право. 